\title{
Friendship and Psychological Well-Being
}

\author{
Shaheen Falki $^{1}$, Fauzia Khatoon ${ }^{2}$
}

\section{ABSTRACT}

"Some people go to priests. Others to poetry.I to my friends". This quotation by Virginia Woolfe would be the perfect way to start this study. "A faithful friend is the medicine of life." Again a quotation but this time by Apocrypha is apt to define the purpose of this study. Everyone has friends - sometimes only one, while at other times, many. But what is the importance of friendship or friends to a person? How does having a friend help us in our time of need, problems and sorrow? Is it possible that friendship relaxes us or reduces our tensions? Does friendship have effect on our well-being and especially psychological well-being? The aim of the current study was to find out what role does Friendship play in Psychological Well-Being. The study was carried on the sample of 200 individuals all aged from 17 to 35. Dimensions of Friendship Scale (SunandaChandna and N.K. Chadha, 1986) and Psychological Well-Being Scale (Bhogle and Jai Prakesh, 1995) were used for the purpose of measurement. Results indicated that there is a significant positive correlation $(r=.723)$ at 0.01 level of significance between friendship and psychological well-being.

\section{Keywords: Friendship, Well-Being, Psychological Well-Being}

It has been rightly said that a friend is someone who can see the truth and pain in you even when you are fooling everyone else. Sometimes it is a friend's shoulder that we need the most during the low phase of our life. At times like these, even our spouse, children or other family members fail to do what a friend does. A friend is the only person who sees us in and out and still loves us the way we are, never trying to change us. And the best part is, unlike our blood relations, it is a mutual choice that makes a friendship work. It has been rightly said by Walter Winchell that, "A real friend is one who walks in when the rest of the world walks out". May be that's why if we have a friend by our side, life doesn't feel lonely anymore. A friend not only shares our problems and gives us the solutions, but also makes us laugh at our problems until we realize that no problem is big enough to make us sad. That's what friends are and that's what friends do. Everyone have friends at all or some stage of our lives. Friendship tends to change over a period

\footnotetext{
${ }^{1}$ Research Scholar, Dept. of Psychology, AMU, Aligarh, Uttar Pradesh, India, India

${ }^{2}$ Research Scholar, Dept. of Psychology, AMU, Aligarh, Uttar Pradesh, India, India

*Responding Author

(C) 2016 S Falki, F Khatoon; licensee IJIP. This is an Open Access Research distributed under the terms of the Creative Commons Attribution License (http://creativecommons.org/licenses/by/2.0), which permits unrestricted use, distribution, and reproduction in any Medium, provided the original work is properly cited.
} 


\section{Friendship and Psychological Well-Being}

of time as we age. Sometimes friendship gets stronger with the passage of time while at other times, friendship tends to fade away gradually over time.

There is no particular definition of friendship. It is a relationship with very vague boundaries. It can have a different meaning or emotional value to different people, and also different meaning or emotional value to the same person at different times. We do not have a specific type of friendship. We have true friends, BFF (Best Friends Forever), good friends, casual friends, work friends, etc. and no matter what name we assign to them, they are our friends. Several characteristics are present in all types of friendships. These include affection, sympathy, empathy, honesty, mutual understanding, compassion, enjoyment of each other's company, trust, and the ability to be oneself, express one's feelings, and make mistakes without fear of judgment from the friend. Friendships doesn't have any code of conducts or legal boundaries or any obligations, it's free from all these ties. Maybe that's why we feel free to be ourselves when we are with friends. It have been perfectly quoted by William Shakespeare that, 'A friend is one that knows you as you are, understands where you have been, accepts what you have become, and still, gently allows you to grow.'

Since 1960's friendship became one of the most talked about and written about topic among relationship scholars. Friendship is very essential element which affects our psychological wellbeing.

In layman language, well-being is a state of being comfortable, healthy and happy with ourselves and our life as whole. But what actually is well-being? Wellbeing, welfare or wellness is a general term for the condition of an individual or group for example their social, economic, psychological, spiritual or medical conditions; While Friedli (2009) defines well-being as feeling good and functioning well. This includes having a fair share of material resources, influence and control, a sense of meaning, belonging and connection with people and place and the capability to manage problems and change.

Psychological well-being refers to how people evaluate or perceive their lives. It is more than simple joy or happiness and it is also more than absence of depression and anxiety. In short, it is the feeling that we are living our life in enjoyable and rewarding way. According to Diener (1997), these evaluations may be in the form of cognitions or in the form of affect. The cognitive aspect includes all information based assessment of one's life which means when a person gives conscious evaluative conclusions about one's satisfaction with life as a whole. The affective aspects deals with a hedonic evaluation guided by emotions and feelings such as frequency with which people experience pleasant/unpleasant moods in relation to their lives. According to Shek (1992), Psychological Well-Being is a state of mentally healthy person who possess a number of positive mental health qualities such as active adjustment to the environment, and unity of 


\section{Friendship and Psychological Well-Being}

personality." Carol Ryff had broken down psychological wellbeing into 6 different components like:

- Self-acceptance -It is how we accept ourselves as we are and how happy and satisfied we are with ourselves.

- Personal growth - It is a feeling of continued development and potential and being open to new experiences, in life.

- Purpose in life -It is having aim in life or having a thing to look forward to everyday.

- Environmental mastery - It is feeling competent and able to manage a complex environment; choosing or creating personally suitable contexts.

- Autonomy - It means evaluating ourselves by personal standards.

- Positive relations with others - It is having warm, satisfying \& trusting relationships.

A World Happiness Database (2010) study found that people with close friendships are happier. It has also been documented that friendship is the most important relationship in an emotional life of an individual between the end of early childhood and onset of full adulthood, and it has also been recorded that friendship is more intense than relationships later in life (Sparks \& Glenn, 2007). It has also been seen that the absence of friends can be emotionally damaging (Williams \& Alex, 2012). As an individual develop emotionally, it has a sequence in which it is noted that friendship comes after parental bonding and before pair bonding.

\section{Psychological Well-Being in Relation to Friendship}

There are numerous studies which prove that friendship has a positive effect on psychological well-being of a person. Friends are important source of positive socialization across the life span (Hartup \& Stevens, 1997) and effects of social relationships on well-being have often been conceptualized in terms of social support that reduces the psychological impact of exposure to stress across the life span (Cohen \& Wills, 1985). As adolescents make the transition into young adulthood, friends are especially important sources of such support (Carbery \& Buhrmester, 1998; Kon \& Losenkov, 1978). It has also been observed that support from friends may buffer the effects of stress experienced by college-aged women perhaps because friends are more available than family members for this aged group, both geographically and psychologically (Martin \& Burks, 1985). People appear to develop fewer cross-gender friendships throughout the life span than same-gender friendships, but a substantial number of both children and adults report having such friends (Booth \& Hess, 1974; Kovacs, Parker \& Hoffman, 1996; Wright, 1989) and it appears that these friendships are related to psychological well-being (Hartup\& Stevens, 1997)

\section{Objective}

- To find out correlation between Friendship and Psychological Well-Being. 


\section{Hypothesis}

- There will be positive effect of Friendship on Psychological Well-being, i.e. those who score more on Dimensions of Friendship Scale will show high level of Psychological Well-being while those who score low on Dimension of Friendship Scale will show low level of Psychological Well-being.

\section{METHOD}

\section{Participants}

The samples of this study were citizens of Aligarh. The sample included 200 subjects. Their ages ranged from 17 to 35 years. The data was collected by the means of questionnaire method for Dimensions of Friendship and Psychological Well-Being.

\section{Measures}

1. Dimension of Friendship Scale developed by Sunanda Chandna \& N.K. Chadha (1986) was used to measure the status of friendship in individuals. According to this scale friendship is divided into 8 dimensions such as enjoyment, acceptance, trust, respect, mutual assistance, confiding, understanding and spontaneity. This scale consists of 64 items out of which 37 were positively scored and 27 were negatively scored. The testretest reliability of the scale was found to be .78 , while the split-half reliability found out in case of even-odd items was .72 while for first-second half was .76. The validity of the scale was found to be .78 .

2. Psychological Well-Being Questionnaire developed by Bhogly \& Jai Prakesh (1995) was used in this study to measure Psychological Well-Being of students. This scale consists of 28 items with alternative response categories - Yes and No, designed to measure 13 dimensions of Psychological Well-Being including meaninglessness, somatic symptoms, selflessness, positive effects, daily activity, life satisfaction, suicidal ideas, personal control, social support, tension, wellness, general efficiency and satisfaction. The reliability was found to be .717. in terms of validity it correlates well, both with Subjective Well-Being Scale $(r=.622)$ and with General Well-Being Scale $(r=.484)$.

\section{Procedure}

The present study is based on citizens of Aligarh, Uttar Pradesh. The subjects in this study were between the ages ranging from 17 to 35. All the subjects were given both Scales, i.e. Dimension of Friendship Scale and Psychological Well-Being Scale to complete. The set of instructions were read out to the subjects for both scales and they were asked to inform if they couldn't understand any statement in any of the scale. In both the scales there was 2 response categories 'Yes' and 'No'. Subjects were also asked to fill the scale truthfully and to the best of their knowledge and finally they were reminded that there are no right and wrong answers. After completing the scale all the subjects were thanked and the completed scales were collected from them. Then the scoring of the scales was started. 


\section{DATA ANALYSIS}

The mean score for Psychological Well-Being was calculated by adding all the scores obtained by individuals divided by the number of individuals $(\mathbf{N}=\mathbf{2 0 0})$. Mean scores of Psychological Well-Being was $\mathbf{1 7 . 9 2}$ while SD was $\mathbf{4 . 7 8 2}$. The mean score of Friendship was $\mathbf{3 7 . 3 2}$ while SD was 11.350. Bivariate Pearson Correlation was used for the present study to know whether there is a relationship between Friendship and Psychological Well-Being and if there is, than what is the direction of that relationship - whether it is positive relation, i.e. if there is high scores on Friendship than there is high score on Psychological Well-Being (direct relationship), or whether there is negative relation, i.e. if there is high score on Friendship than there is low score on Psychological Well-Being (inverse relationship). The value obtained by Bivariate Pearson Correlation is .723 which is significant at 0.01 level.

Table 1. Indicates Mean \& SD of Friendship and Psychological Well-Being Descriptive Statistics

\begin{tabular}{|l|l|l|l|}
\hline Variables & Mean & Std. Deviation & $\mathbf{N}$ \\
\hline Psychological & 17.92 & 4.782 & 200 \\
Well-Being & 37.32 & 11.350 & 200 \\
Friendship & & \\
\hline
\end{tabular}

Table 2. Indicates correlation between Friendship and Psychological Well-Being Correlations

\begin{tabular}{|ll|l|l|}
\hline Variables & PWB & Friendship \\
\hline \multirow{2}{*}{\begin{tabular}{ll|l|} 
Psychological \\
Well-Being
\end{tabular}} & Pearson Correlation & 1 & $.723^{* *}$ \\
& $\mathbf{N}$ & & .000 \\
\hline \multirow{2}{*}{ Friendship } & Pearson Correlation & 200 & 200 \\
& Sig. (2-tailed) & $.723^{* *}$ & 1 \\
& $\mathbf{N}$ & 2000 & \\
\hline
\end{tabular}

**. Correlation is significant at the 0.01 level (2-tailed).

\section{RESULT AND DISCUSSION}

The result revealed by Table 2 shows that there is a significant correlation between Friendship and Psychological Well-Being. The value of correlation is .723 which is significant at 0.01 level of significance. It also shows the direction of relationship, which is positive meaning that when friendship increases than Psychological Well-Being also increases. This means our null hypothesis is rejected, i.e. there is significant correlation between the scores of Friendship and Psychological Well-Being. 


\section{Friendship and Psychological Well-Being}

On the basis of correlation, it appeared that Friendship has an on overall positive effect on Psychological Well-Being. The purpose of this paper is to contribute to a theoretical understanding of role of friendship in promoting psychological well-being. The findings of the present study clearly indicate that friendship plays an important role in psychological well-being of an individual. Though the sample of the present study was quite small, previous researches in this area supports the result so this can be generalized.

It is seen that friendship is a very important part of an individual's life. Whether its childhood friendship, teenagers' friendship or a friendship in adulthood and old age. Irwin Sarason rightly quoted that - 'Good friends are good for your health.' Many a times it is only friendship that gives us strength to walk in darkness. 'I would rather walk with a friend in the dark, than alone in the light.' A quote by Helen Keller explains this feeling very well. And it's not only in sadness that a person needs friends but also in their happiness, friends don't lose their importance. We all want to share our happiest moments with our friends - whether it's our results, our first job, our love confessions, or our retirement news.

\section{Acknowledgments}

The author appreciates all those who participated in the study and helped to facilitate the research process.

\section{Conflict of Interests}

The author declared no conflict of interests.

\section{REFERENCE}

Booth, A., \& Hess, E. (1974). Cross-sex friendship. Journal of Marriage and the Family, 36, 38- 47.

Carbery, J., \&Buhrmester, D. (1998). Friendship and need fulfillment during three phases of young adulthood. Journal of Social and Personal Relationships, 15, 393-409.

Cohen, S., \& Wills, T. A. (1985). Stress, social support, and buffering hypothesis. Psychological Bulletin, 98, 310-357.

Diener, E., \& Fujita, F. (1997). Social comparisions and subjective well-being. In B. Buunk\& R. Gibbons (Eds.), Health, coping, and social comparison. (pp. 329-357). Mahwah, NJ: Eribaum.

Friedli, L. (2009) 'Mental health, resilience and inequalities', World Health Organization.

Hartup, W. W., \& Stevens, N. (1997). Friendships and adaptations in the life course. Psychological Bulletin, 121, 355-370.

Kon, I. S., \&Losenkov, V. A. (1978). Friendship in adolescence: Values and Behavior. Journal of Marriage and Family, 40, 143-155.

Kovacs, D. M., Parker, J. G., \& Hoffman, L.W. (1996). Behavioral, affective and social correlates of involvement in cross-sex friendship in elementary school. Child Development, 67, 2269-2286. 


\section{Friendship and Psychological Well-Being}

Martin, B., \& Burks, N. (1985). Family and nonfamily components of social support as buffers of stress for college women. Journal of Applied Social Psychology, 15, 448-465.

Revisited from Boardofwisdom.Comhttp://boardofwisdom.com/togo/?viewid=1005\&listname=Friendshi p\&start $=51 \#$.Vd8ILvNViko

Revisited from En.Wikipedia.Org https://en.wikipedia.org/wiki/Well-being

Revisited from Thoughtcatalog.Com http://thoughtcatalog.com/mandy-zucker/2013/10/50-quotes-about-friendship/

Shek, D. (1992). Meaning in life and psychological well-being: an empirical study using the Chinese version of the purpose in life questionnaire. Journal of Genetic Psychology, 153, 185-190.

Sparks, Glenn. (2007). Study shows what makes college buddies lifelong friends. Purdue University.

Williams, Alex. (2012). "Friends of a Certain Age: Why Is It Hard To Make Friends Over 30?". The New York Times. Retrieved October 25, 2012.

World Happiness Database. Cited in Brace, N. \& Byford, J. (Ed.) (2010) Discovering psychology: What is friendship. The Open university. ISBN 1-84873-466-2.

Wright, P. H. (1989). Gender differences in adults same and cross-gender friendships. In R.G. Adams \& R. Blieszner (Eds.), Older Adults Friendship: Structure \& Process (pp. 197221). Newbury Park, CA: Sage.

How to cite this article: S Falki, F Khatoon (2016), Friendship and Psychological Well-Being, International Journal of Indian Psychology, Volume 3, Issue 4, No. 77, ISSN:2348-5396 (e), ISSN:2349-3429 (p), DIP:18.01.073/20160304, ISBN: 978-1-365-51571-2 